\title{
Antibiotic R2, a new angucyclinone compound from Streptosporangium sp. Sg3
}

\author{
Hadjira Boudjella ${ }^{1}$, Abdelghani Zitouni ${ }^{1}$, Yannick Coppel ${ }^{2}$, Florence Mathieu ${ }^{3}$, Marie-Carmen Monje ${ }^{3}$, \\ Nasserdine Sabaou ${ }^{1}$ and Ahmed Lebrihi ${ }^{3}$
}

The Journal of Antibiotics (2010) 63, 709-711; doi:10.1038/ja.2010.111; published online 13 October 2010

Keywords: actinomycete; new angucyclinone; Streptosporangium; structure elucidation

Angucyclinones are a subclass of angucyclines, which are defined as microbial quinone natural products related to tetracyclines and anthracyclines and bearing, as characteristic structural feature, a tetracyclic benz $[a]$ anthracene ring system assembled in an angular manner. ${ }^{1}$ This structural moiety is biosynthetically derived from a decaketide chain formed via the polyketide biosynthetic pathway. The term 'angucycline' includes molecules with hydrolysable sugar moieties, whereas 'angucyclinone' refers to a sugarless compound or a compound with a $C$-glycosidic linked sugar moiety. ${ }^{1,2}$ Angucyclines are isolated from the fermentation broth of actinomycetes, mostly from the genus Streptomyces, but also from Actinomadura, Nocardia and Streptosporangium genera. ${ }^{1}$ Angucyclines show a broad spectrum of biological activities including antitumor, ${ }^{1,2}$ antibacterial, antifungal, antiviral, ${ }^{3,4}$ enzyme inhibitory ${ }^{5,6}$ and platelet aggregation inhibitory properties. ${ }^{7,8}$ In a continuous search for new bioactive compounds from actinomycetes other than the genus Streptomyces, several Saharan soil samples collected in arid ecosystems were explored. ${ }^{9-11}$ Among the isolates, we were interested by a new actinomycete strain belonging to the genus Streptosporangium and producing a new compound (R2) identified as a new angucyclinone. This paper describes the isolation, structure elucidation and antimicrobial activities of compound R2.

Details on the isolation and the taxonomy of the producing organism Streptosporangium sp. Sg3 were described in a previous paper. ${ }^{11}$ To isolate compound R2, Streptosporangium sp. Sg3 was cultivated at $30^{\circ} \mathrm{C}$ for 9 days in Erlenmeyer flasks $(500 \mathrm{ml})$ containing $100 \mathrm{ml}$ of ISP2 broth (yeast extract $4 \mathrm{~g}$, malt extract $10 \mathrm{~g}$, glucose $4 \mathrm{~g}$, in 11 distilled water, $\mathrm{pH} 7.2$ ) on a rotary shaker (250 r.p.m.). The cultures (81) were centrifuged and filtered to remove mycelium. The culture filtrate was extracted with an equal volume of $n$-butanol to generate a crude extract $(1.9 \mathrm{~g})$. The latter was fractionated by size exclusion chromatography on Sephadex $\mathrm{LH}-20\left(75 \% \mathrm{MeOH}\right.$ in $\mathrm{H}_{2} \mathrm{O}$ ), resulting in five fractions, I-V. Fraction IV including R2, was of red color and exhibited an antibacterial activity. It was subjected to semipreparative reversed-phase HPLC using an Interchim UP5ODB column $(250 \times 7.8 \mathrm{~mm})$ (Interchim, Montluçon, France) and developed using a continuous grade from 20 to $75 \% \mathrm{MeOH}$ in $\mathrm{H}_{2} \mathrm{O}$ (UV detection at $220 \mathrm{~nm}$ ), yielding three active fractions $(1,2,3)$. The major peak $\mathbf{2}$ with the main antibacterial activity was subjected to repeated HPLC to yield $3.5 \mathrm{mg}$ of compound $\mathbf{R} 2$.

Compound $\mathbf{R} 2$ was obtained as a red powder (optical rotation $[\alpha]_{\mathrm{D}}^{21}+56(c 0.11, \mathrm{MeOH})$. The ESI-MS spectrum contained an ion peak at $m / z 475.1[\mathrm{M}-\mathrm{H}]^{-}$, and its molecular formula was determined by HRESI-MS analysis as $\mathrm{C}_{26} \mathrm{H}_{19} \mathrm{O}_{9}$ (calcd 475.43 for $(\mathrm{M}-\mathrm{H})^{-}$, found 475.43). The UV absorption maximum at $535 \mathrm{~nm}$ was because of the red color and suggested a quinone chromophore. Absorptions at 3259, 2949 and $1721 \mathrm{~cm}^{-1}$ in the IR spectrum of $\mathbf{R} 2$ were characteristic of hydroxy, methyl and carbonyl groups, respectively. $\mathbf{R} 2$ was soluble in $\mathrm{MeOH}$ and DMSO, and insoluble in chloroform, $n$-hexane and $\mathrm{H}_{2} \mathrm{O}$.

The structure of $\mathbf{R} 2$ (Figure 1) was determined by ${ }^{1} \mathrm{H}$ and ${ }^{13} \mathrm{C}$ NMR spectroscopy and by using ${ }^{1} \mathrm{H}-{ }^{1} \mathrm{H}$ COSY45, ${ }^{1} \mathrm{H}-{ }^{13} \mathrm{C}$ HMQC and ${ }^{1} \mathrm{H}-{ }^{13} \mathrm{C}$ HMBC experiments. The ${ }^{1} \mathrm{H}$ and ${ }^{13} \mathrm{C}$ chemical shifts of compound $\mathbf{R} 2$ are given in Table 1 . The ${ }^{13} \mathrm{C}$ and Heteronuclear SingleQuantum Correlation spectra showed 26 carbon signals with a large number of quaternary carbons (17 out of 26$)$. From the ${ }^{13} \mathrm{C}$ data, it was possible to discern two keto-carbonyl groups ( $\delta c 188.4$ and 186.5), one carboxylic acid group $(\delta c 174.1), 19 \mathrm{sp}^{2}$-hybridized carbons $(\delta c$ from 160.2 to 114.7$)$, two $\mathrm{sp}^{3}$-hybridized carbons bearing an electronegative heteroatom $(\delta c 73.0$ and 72.5$)$, one $\mathrm{sp}^{3}$-hybridized carbon $(\delta c$ 22.6) and two methyl groups ( $\delta c 22.4$ and 12.4). In $\mathrm{CD}_{3} \mathrm{OD}$, the ${ }^{1} \mathrm{H}$ NMR spectrum revealed two ortho-coupled aromatic protons $\left(\delta_{H}\right.$ 7.82 and $7.66,2 \mathrm{H}, J=7.5 \mathrm{~Hz})$, two aromatic protons $\left(\delta_{H} 8.24\right.$ and $7.02,2 \mathrm{H}, \mathrm{s})$, an $\mathrm{AB}$ system $\left(\delta_{H} 4.45\right.$ and $\left.4.36, J_{A B}=10.7 \mathrm{~Hz}\right)$, an ethyl group $\left(\delta_{H} 2.83\right.$ and $\left.1.32,5 \mathrm{H}, J=7.4 \mathrm{~Hz}\right)$ and a methyl group $\left(\delta_{H} 2.70\right.$, $3 \mathrm{H}, \mathrm{s})$. In DMSO, NMR signals were significantly broader but the

${ }^{1}$ Laboratoire de Recherche sur les Produits Bioactifs et la Valorisation de la Biomasse, Ecole Normale Supérieure de Kouba, Alger, Algéria; ${ }^{2}$ CNRS, LCC (Laboratoire de Chimie de Coordination), Toulouse, France and ${ }^{3}$ Département 'Bioprocédés \& Systèmes Microbiens', ENSAT/INPT, Université de Toulouse, Laboratoire de Génie Chimique, UMR 5503 (CNRS/INPT/UPS), Castanet-Tolosan, France

Correspondence: Professor A Lebrihi, Département of ‘Bioprocédés \& Systèmes microbiens', ENSAT/INPT, Université de Toulouse, Laboratoire de Génie Chimique, UMR 5503 (CNRS/INPT/UPS), 1 avenue de l'Agrobiopole, B.P. 32 607, Auzeville-Tolosane, Castanet-Tolosan 31 326, France.

E-mail: lebrihi@ensat.fr

Received 27 March 2010; revised 5 August 2010; accepted 3 September 2010; published online 13 October 2010 
a<smiles>Cc1cc2c(c(O)c1C(=O)O)-c1c(cc3c(O)c1C(=O)c1ccc(F)c(O)c1C3=O)C(O)C2O</smiles>

b $\quad-\quad-{ }^{1} \mathrm{H}-{ }^{-1} \mathrm{H}$ COSY correlations - ${ }^{1} \mathrm{H}^{-13} \mathrm{C}$ HMBC correlations

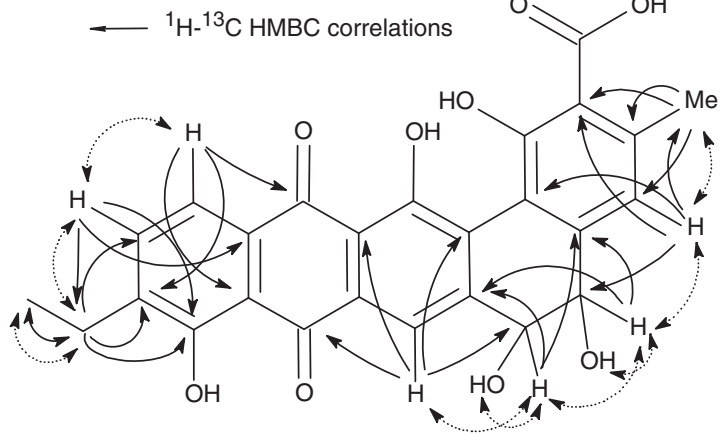

Figure 1 Structure of angucyclinone R2 (a), and HMBC and COSY correlations (b).

Table $1{ }^{1} \mathrm{H}$ and ${ }^{13} \mathrm{C}$ NMR data assignments of $\mathrm{CD}_{3} \mathrm{OD}$ at $298 \mathrm{~K}$

\begin{tabular}{|c|c|c|}
\hline Position & $\delta_{\mathrm{C}}$, mult. & $\delta_{\mathrm{H}}(\mathrm{J}$ in $\mathrm{Hz})$ \\
\hline 1 & $160.2, \mathrm{qC}^{\mathrm{a}}$ & - \\
\hline 2 & $118.5, \mathrm{qC}$ & - \\
\hline 3 & $143.1, q C$ & - \\
\hline 4 & $116.9, \mathrm{CH}$ & $7.02, \mathrm{~s}$ \\
\hline $4 a$ & $147.4, \mathrm{qC}$ & - \\
\hline 5 & $72.5, \mathrm{CH}$ & $4.36, \mathrm{~d}(10.7)$ \\
\hline 6 & 73.0, $\mathrm{CH}$ & $4.45, \mathrm{~d}(10.7)$ \\
\hline $6 a$ & 141.9, qC & - \\
\hline 7 & $114.7, \mathrm{CH}$ & $8.24, \mathrm{~s}$ \\
\hline $7 a$ & $131.6, \mathrm{qC}$ & - \\
\hline 8 & 188.4, qC & - \\
\hline $8 a$ & 115.2 qC & - \\
\hline 9 & 160.1, qC & - \\
\hline 10 & 139.9, qC & - \\
\hline 11 & $135.3, \mathrm{CH}$ & $7.66, d(7.5)$ \\
\hline 12 & $118.7, \mathrm{CH}$ & $7.82, d(7.5)$ \\
\hline $12 a$ & 132.0, qC & - \\
\hline 13 & 186.5, qC & - \\
\hline $13 a$ & 117.4, qC & - \\
\hline 14 & 158.6, $\mathrm{qC}^{\mathrm{a}}$ & - \\
\hline $14 a$ & 128.6, qC & - \\
\hline $14 \mathrm{~b}$ & 114.9, qC & - \\
\hline 15 & 174.1, qC & - \\
\hline 16 & $22.4, \mathrm{CH}_{3}$ & $2.70, \mathrm{~s}$ \\
\hline 17 & 22.6, $\mathrm{CH}_{2}$ & $2.83, \mathrm{q}(7.4)$ \\
\hline 18 & $12.4, \mathrm{CH}_{3}$ & $1.32, \mathrm{t}(7.4)$ \\
\hline $\mathrm{OH}-1^{b, c}$ & - & $17.64, \mathrm{~s}$ \\
\hline $\mathrm{OH}-5^{\mathrm{c}}$ & - & $5.69, \mathrm{~s}$ \\
\hline $\mathrm{OH}-6^{\mathrm{c}}$ & - & $5.92, \mathrm{~s}$ \\
\hline $\mathrm{OH}-9^{b, c}$ & - & $13.98, \mathrm{~s}$ \\
\hline $\mathrm{OH}-14^{\mathrm{b}, \mathrm{c}}$ & - & $13.08, \mathrm{~s}$ \\
\hline $\mathrm{COOH}^{\mathrm{b}, \mathrm{c}}$ & - & $13.20, \mathrm{~s}$ \\
\hline
\end{tabular}

a,b Resonance assignment may be interchangeable.

In DMSO- $d_{6}$.

Mult. stands for multiplicity. $\mathrm{qC}, \mathrm{CH}, \mathrm{CH}_{2}$ and $\mathrm{CH}_{3}$ indicate respectively quaternary, tertiary, secondary and primary carbons.

${ }^{1} \mathrm{H}$ NMR spectrum showed additional resonances: four enol or carboxylic acid protons $\left(\delta_{H} 17.64,13.98,13.20\right.$ and 13.08, $\left.4 \mathrm{H}, \mathrm{s}\right)$ and two hydroxyl signals $\left(\delta_{H} 5.92\right.$ and $\left.5.69,2 \mathrm{H}, \mathrm{s}\right)$. The $2 \mathrm{D}{ }^{1} \mathrm{H}-{ }^{1} \mathrm{H}$ and ${ }^{1} \mathrm{H}-{ }^{13} \mathrm{C}$ experiments and especially the long range ${ }^{1} \mathrm{H}-{ }^{13} \mathrm{C}$ couplings observed in the $\mathrm{HMBC}$ spectrum permitted to establish the presence of a benzo $[a]$ naphtacenequinone skeleton. Only four carbons did not show any correlation in the HMBC spectrum (C1, C7a, C14 and C15). Their assignment has been confirmed by comparison with NMR data of the pradimicin antibiotic family. ${ }^{12}$ The peak of the four enol or carboxylic acid protons was too broad to give HMBC correlations and so could not be exactly assigned. The observed coupling constant of $10.7 \mathrm{~Hz}$ between $\mathrm{H} 5$ and $\mathrm{H} 6$ suggested that the dihedral angles between $\mathrm{H} 5$ and $\mathrm{H} 6$ are near $180^{\circ}$ and is consistent with a trans-diaxal orientation. This value is similar with ones found for related compounds ${ }^{3,12}$ where a $5 \mathrm{~S}, 6 \mathrm{~S}$ absolute configuration has been deduced.

The structure of $\mathbf{R} \mathbf{2}$ was determined to be a benzo $[a]$ naphtacene2-carboxylic acid,4,7,11,12-tetrahydro-1,5,6,9,14-pentahydroxy-8,13dioxo-3-methyl-10-ethyl.

The minimum inhibitory concentrations (MICs) of $\mathbf{R} 2$ were determined by a conventional agar dilution method using nutrient agar medium. Compound R2 showed strong activity against the Gram-positive bacteria Micrococcus luteus ATCC 9314 and Bacillus subtilis ATCC 6633 (MICs $=0.5$ and $1 \mu \mathrm{g} \mathrm{ml}^{-1}$, respectively), and moderate activity against Staphylococcus aureus CIP 7625 $\left(\mathrm{MIC}=10 \mu \mathrm{g} \mathrm{ml}^{-1}\right)$. A weak activity was observed against Listeria monocytogenes CIP 82110 and Mycobacterium smegmatis ATCC 607 (MICs $=40$ and $50 \mu \mathrm{g} \mathrm{ml}^{-1}$, respectively). Compound $\mathbf{R} 2$ showed no activity (MICs $>100 \mu \mathrm{g} \mathrm{ml}^{-1}$ ) against the Gram-negative bacteria (Escherichia coli ATCC 10536 and Pseudomonas fluorescens number 412), the fungi (Mucor ramannianus NRRL 1829 and Aspergillus carbonarius number M333) and the yeasts (Saccharomyces cerevisiae ATCC 4226 and Candida albicans number 224).

In conclusion, from the results presented in this paper, we found that strain Streptosporangium sp. Sg3 produces a new angucyclinone that displayed antibacterial activities.

\section{ACKNOWLEDGEMENTS}

A part of this work was supported by the grant from 'Comite d'Evaluation et de Prospective de Coopération Inter-universitaire Franco-Algérienne’ (Programme Hubert Curien Tassili).

1 Rohr, J. \& Thiericke, R. Angucycline group antibiotics. Nat. Prod. Rep. 9, 103-137 (1992).

2 Krohn, K. \& Rohr, J. Angucyclines: total syntheses, new structures, and biosynthetic studies of an emerging new class of antibiotics. Top. Curr. Chem. 188, 128-195 (1997).

3 Tsunakawa, M. et al. The structures of pradimicins A, B, and C: a novel family of antifungal antibiotics. J. Org. Chem. 54, 2532-2536 (1989).

4 Kondo, S., Gomi, S., Ikeda, D., Hamada, M. \& Takeuchi, T. Antifungal and antiviral activities of benanomycins and their analogues. J. Antibiot. 44, 1228-1236 (1991). 
5 Tsurumi, Y. et al. WS79089A, B and C, new endothelin converting enzyme inhibitors isolated from Streptosporangium roseum No. 79089. Taxonomy, fermentation, isolation, physico-chemical properties and biological activities. J. Antibiot. 47, 619-630 (1994).

6 Matsuda, Y. \& Kase, H. KS-619-1, a new inhibitor of Ca2+ and calmodulin-dependent cyclic nucleotide phosphodiesterase from Streptomyces californicus. J. Antibiot. 40, 1104-1110 (1987).

7 Kawashima, A., Kishimura, Y., Tamai, M. \& Hanada, K. New platelet aggregation inhibitors. Chem. Pharm. Bull. 37, 3429-3431 (1989).

8 Kawashima, A. et al. PI-083, a new platelet aggregation inhibitor. J. Antibiot. 41, 1913-1914 (1988)
9 Sabaou, N. et al. Les sols des oasis du Sahara algérien, source d'actinomycètes rares producteurs d'antibiotiques. Sécheresse 9, 147-153 (1998).

10 Zitouni, A. et al. Saccharothrix algeriensis sp. nov., isolated from Saharan soil. Int. J. Syst. Evol. Microbiol. 54, 1377-1381 (2004).

11 Boudjella, H. et al. Isolation and partial characterization of pigment-like antibiotics produced by a new strain of Streptosporangium isolated from an Algerian soil. J. Appl. Microbiol. 103, 228-236 (2007).

12 Tsuno, T. et al. Biosynthesis of the pradimicin family of antibiotics. II. Fermentation, isolation and structure determination of metabolites associated with the pradimicins biosynthesis. J. Antibiot. 46, 420-429 (1993). 